\title{
HUBUNGAN ANTARA NILAI ADVERSITY QUOTIENT (AQ) TERHADAP HASIL BELAJAR BIOLOGI
}

\author{
Mahrawi $^{1)}$, Usman $^{2)}$, Anggi Tania Musliyani ${ }^{3)}$ \\ ${ }^{1,2,3}$ Pendidikan Biologi, Universitas Sultan Ageng Tirtayasa \\ email $^{l}$ : mahrawi@untirta.ac.id \\ email $^{2}$ : usman@untirta.ac.id \\ email ${ }^{3}$ : anggitania64@gmail.com
}

\begin{abstract}
ABSTRAK: Penelitian ini bertujuan untuk mengetahui hubungan antara nilai Adversity Quotient (AQ) terhadap hasil belajar biologi. Metode penelitian yang digunakan yaitu deskriptif korelasional. Penelitian dilaksanakan di SMAN 13 Kabupten Tangerang kelas XI MIPA 1 dan XI MIPA 3 semester genap tahun ajaran 2020/2021. Teknik pengambilan sampel menggunakan simple random sampling. Teknik pengumpulan data yang digunakan yaitu Adversity Reponse Profile (ARP), dan nilai Penilaian Akhir Tahun (PAT) biologi. Teknik analisis data menggunakan uji koefisien korelasi, koefisien determinasi, dan regresi linier sederhana. Hasil penelitian menunjukkan bahwa rata-rata nilai Adversity Quotient (AQ) peserta didik berada pada kategori tinggi dengan persentase sebesar 94,11\% dan hasil belajar biologi dengan kategori baik yaitu 35,29\%. Nilai pearson korelasi yang diperoleh yaitu sebesar 0,640. Korelasi tersebut menunjukkan bahwa tingkat hubungan antara nilai Adversity Quotient (AQ) terhadap hasil belajar biologi berada pada kategori kuat. Kesimpulan yang didapat yaitu terdapat hubungan positif yang signifikan antara nilai Adversity Quotient (AQ) terhadap hasil belajar biologi.
\end{abstract}

Keywords: Adversity Quotient (AQ), Hasil Belajar Biologi, Ranah Kognitif.

ABSTRACT: The research is purposed to find out about relation between Adversity Quotient (AQ) value to biology result studies. The research used descriptive correlational method. This study was conducted in SMAN 13 Tangerang District class X IPA 1 and XI MIPA 3 even semester school year 2020/2021. The sampling technique use was the simple random sampling. Data collection technique using Adversity Response Profile (ARP) and Biology End of Year Assessment (PAT). The data analysis technique used correlation coefficient test, coefficient determination, and simple linier regression. The result showed an average ability of Adversity Quotient $(A Q)$ value student in the high category with a percentage of $94,11 \%$ and biology result studies in the good category that is $35,29 \%$. The pearson correlation value obtained is 0,640. Correlation shows that he level relation between Adversity Quotient ( $A Q)$ value to biology result studies in strong category. The conclusion obtained is that there is significant positive correlation between Adversity Quotient (AQ) value to biology result studies.

Keywords: Adversity Quotient (AQ), Biology Result Studies, Cognitive aspect

\section{PENDAHULUAN}

Kualitas pendidikan dapat dilihat dari proses pembelajaran. Secara umum, proses pembelajaran yang dilaksanakan berkualitas, maka pendidikan akan semakin berkualitas. 
Namun, proses pembelajaran masih menjadi permasalahan pendidikan di Indonesia. Penelitian Priyayi et al (2018) menyimpulkan proses belajar mengajar di Indonesia masih belum optimal, dikarenakan terdapat permasalahan pada prosesnya sebesar $80,61 \%$ yang berasal dari peserta didik. Permasalahan yang sering ditemui yaitu perjuangan yang rendah ketika belajar dan malu bertanya jika kurang mengerti sehingga berpengaruh pada hasil belajar.

Hasil belajar termasuk bagian penting proses belajar mengajar. Hasil belajar sebagai parameter kesuksesan proses pembelajaran dapat memberikan informasi seberapa jauh pemahaman peserta didik mengenai materi yang disampaikan. Berdasarkan data Kemendikbud (2019) hasil belajar di Indonesia tahun 2019 untuk peminatan IPA dari nilai UN biologi menempati urutan kedua terendah secara nasional dengan rata-rata nilai 50,61. Penelitian Kusnani et al., (2016) menyimpulkan bahwa hasil penilaian akhir pada semester genap biologi termasuk kedalam kategori rendah dengan ratarata tuntas $29,02 \%$ dan tidak tuntas 70,98\%. Hasil belajar biologi yang rendah dipengaruhi oleh daya ingat peserta didik yang kurang terhadap materi, perjuangan yang rendah ketika belajar, materi yang sulit untuk dipahami, dan cara menjawab soal cenderung menebak karena soal terlalu sulit untuk dikerjakan.

Karakteristik biologi dalam pembelajaran biologi memerlukan kemampuan multisensor untuk memahami suatu peristiwa atau suatu mekanisme yang kompleks Peserta didik yang tidak tertarik dengan pembelajaran biologi akan menganggap pembelajaran yang dilakukan sulit dan membosankan, sehinggga minat dalam belajar dan keinginan menghadapi kesulitan harus muncul dari dalam diri peserta didik. Penelitian Zamzami et al., (2020) menyimpulkan bahwa $66,52 \%$ kesulitan belajar berasal dari peserta didik. Peserta didik kurang paham terhadap kesulitan belajar dan merasa kesulitan belajar tidak bisa berubah karena tidak ada yang salah dengan cara yang dilakukan untuk belajar. Menurut Achru (2019) peserta didik berjuang mengikuti pembelajaran dengan sungguh-sungguh dan mengadakan tambahan jam belajar di rumah tetapi hasil belajarnya tetap kurang memuaskan. Hal ini didukung oleh pendapat Susanto (2016) bahwa perjuangan saja tidak cukup untuk mengatasi kesulitan dan mencapai keberhasilan, maka setiap peserta didik perlu memiliki kecerdasan untuk mengatasi kesulitan. Kecerdasan dalam situasi sulit muncul dalam diri yang disebut dengan Adversity Quotient (AQ).

Adversity Quotient (AQ) dikonsepkan oleh Paul G Stoltz sebagai bentuk kecerdasan ketegaran atau daya juang. Adversity Quotient yang dimiliki seseorang mampu mengubah rintangan menjadi kesempatan, karena kecerdasan ini dapat menentukan sejauh mana seseorang bertahan menghadapi kesulitan dalam belajar maupun kesulitan dalam hidup (Agustina \& Komalasai, 2014; Suhartono, 2017). Pembelajaran di Indonesia kurang memperhatikan kecerdasan Adversity Quotient karena umumnya pembelajaran hanya memperhatikan kecerdasan intelektual (IQ), tanpa disadari bahwa Adversity Quotient memiliki pengaruh ketika mengatasi kesulitan belajar terutama untuk memperoleh hasil belajar. Adversity Quotient (AQ) penting untuk diperhatikan oleh peserta didik dan 
pendidik guna menciptakan proses pembelajaran dan hasil belajar yang baik.

Hasil wawancara dengan guru biologi kelas XI di SMAN 13 Kabupaten Tangerang diperoleh informasi bahwa peserta didik menyukai dan antusias dalam pembelajaran biologi, memiliki perjuangan yang tinggi ketika belajar, akan tetapi hasil belajar saat Penilaian Akhir Tahun (PAT) mayoritas memperoleh nilai yang rendah. Peserta didik kesulitan dalam memahami materi, malu bertanya dan pasif, kurang percaya diri, dan kesulitan menjawab soal ujian. Guru biologi sering melakukan refleksi pembelajaran, tetapi secara individual peserta didik kurang mendapat ruang untuk menyampaikan kesulitan dalam pembelajaran. Cara yang dilakukan peserta didik ketika mengatasi kesulitan dalam belajar yaitu membaca buku, mencari di internet, bertanya teman, dan bertanya guru. Respon terhadap menunjukkan adanya Adversity Quotient (AQ) yang berbeda pada setiap peserta didik. Guru biologi belum mengetahui Adversity Quotient (AQ) yang dimiliki peserta didik, sehingga diperlukan perhatian lebih kepada peserta didik untuk mengatasi permasalahan kesulitan. Oleh karena itu penting untuk diadakannya penelitian yang memiliki tujuan untuk mengetahui hubungan antara nilai Adversity Quotient (AQ) terhadap hasil belajar biologi di SMAN 13 Kab. Tangerang agar menjadi tolak ukur dalam hasil belajar biologi.

\section{METODE PENELITIAN}

Penelitian ini dilaksanakan di SMAN 13 Kabupaten Tangerang bulan April - Juni 2021 tahun ajaran 2020/2021. Populasi penelitian ini yaitu seluruh peserta didik kelas XI MIPA dengan sampel yang digunakan yaitu kelas XI MIPA 1 dan XI MIPA 3 sebanyak 68 peserta didik yang diambil dengan teknik random sampling (secara acak) karena tidak ada kelas unggulan. Penelitian ini menggunakan metode deskriptif korelasional dengan tujuan untuk mengetahui ada atau tidak hubungan antara variabel (X) terhadap variabel (Y).

Teknik pengumpulan data dengan non-tes. Instrumen yang dipakai adalah Adversity Reponse Profile (ARP), dan nilai Penilaian Akhir Tahun (PAT) biologi semester genap yang diperoleh dari guru biologi berupa nilai murni pada aspek kognitif. ARP berisi 40 pernyataan berdasarkan dimensi CO2RE yaitu Control (kendali), Ownership and Origin (asal-usul dan pengakuan), Reach (jangkauan) Endurance (daya tahan). yang disusun berdasarkan skala likert. Skor ARP pada setiap peserta didik dijumlahkan kemudian dikelompokkan ke dalam 3 kategori yaitu tipe Climbers (AQ tinggi) Campers (AQ sedang) dan Quitters (AQ rendah). Pengkategorian pada masing-masing dimensi CO2RE dengan menjumlah seluruh skor pada masing-masing dimensi CO2RE.

Teknik Analisis Data yang digunakan yaitu uji prasyarat dan uji hipotesis. Uji prasyarat berupa uji normalitas, uji homogenitas dan uji linearitas yang dilakukan menggunakan aplikasi SPSS versi 23. Uji normalitas dengan menggunakan kolmogorov-Smirnov. Uji homogenitas dengan menggunakan Levene statistic. Jika data yang diperoleh normal, homogen, dan linear maka selanjutnya dilakukan uji hipotesis. Uji Hipotesis menggunakan uji koefisien korelasi, koefisen determinasi, dan regresi linear sederhana menggunakan SPSS versi 23. 


\section{HASIL DAN PEMBAHASAN}

1. Nilai Adversity Quotient (AQ)

Nilai Adversity Quotient (AQ) didapat dari hasil Adversity Reponse Profile (ARP) yang diinterpretasi ke dalam kategori tipe Adversity Quotient (AQ menurut modifikasi Stoltz (2007) yaitu peserta didik dengan AQ tinggi tergolong tipe Climbers, AQ sedang tergolong tipe Campers, dan AQ rendah tergolong ke dalam tipe Quitters. Hasil nilai Adversity Quotient (AQ) dapat dilihat pada gambar 1 .

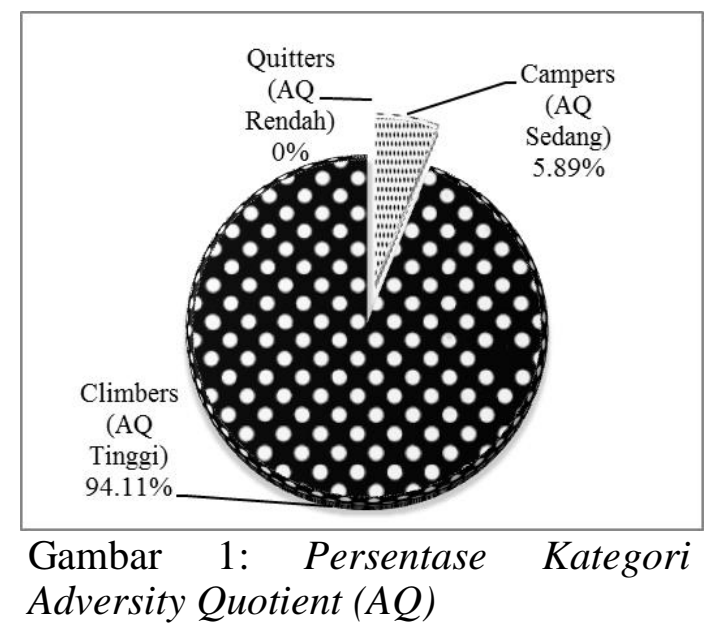

Gambar 1 menunjukkan bahwa kategori Adversity Quotient (AQ) yang diperoleh peserta didik tergolong ke dalam tinggi dan sedang, sedangkan peserta didik dengan tingkat Adversity Quotient (AQ) rendah tidak muncul pada penelitian ini. Berdasarkan gambar 1 bahwa peserta didik dengan kategori Adversity Quotient (AQ) tinggi sebanyak $94,11 \%$ termasuk tipe Climbers dan kategori Adversity Quotient (AQ) sedang tipe Campers sebanyak 5,89\%. Hasil tersebut dapat diartikan bahwa peserta didik mempunyai kemampuan yang baik ketika mengatasi permasalahan dalam pembelajaran, dan mengatasi permasalahan dalam menjawab soal ujian biologi. Hal ini didukung oleh Ronnie (2006) bahwa dasar dari belajar ialah mengatasi kesulitan. Kesulitan peserta didik memiliki arti bahwa masih bisa di atasi dengan mempertajam pikiran, mengasah kecerdasan, dan mempertajam kepekaan perasaan.

Peserta didik tipe Climbers merupakan peserta didik dengan Adversity Quotient (AQ) tinggi. Berdasarkan pernyataan Adversity Reponse Profile (ARP) peserta didik tipe Climbers rajin belajar sehingga mampu mengatasi kesulitan, menggali banyak informasi untuk lebih memahami materi, berjuang sungguhsungguh ketika belajar, tetap mengumpulkan dan mengerjakan tugas meskipun tugas yang diberikan sulit, tetap fokus ketika sedang belajar untuk ujian, tidak putus asa dalam mengatasi permasalahan belajar. Sejalan dengan penelitian yang dilakukan Septianingtyas dan Jusra (2020) bahwa tipe Climbers mampu memahami permasalahan dengan baik, mempunyai sikap pantang menyerah sebelum menemukan penyelesaian, dan sangat mementingkan proses untuk memperoleh hasil akhir yang baik. Tipe Climbers mampu memotivasi dirinya, mempunyai semangat tinggi, memiliki perjuangan besar untuk memperoleh yang terbaik dalam hidup, dan mampu mewujudkan segala sesuatu sehingga memperoleh hasil belajar yang memuaskan (Stoltz, 2007). Peserta didik tipe Climbers tidak pantang menyerah dalam mengatasi permasalahan yang menimpahnya sampai terselesaikan dengan baik.

Peserta didik dengan kategori Adversity Quotient (AQ) sedang tipe Campers sebanyak 5,89\%. Campers merupakan peserta didik dengan Adversity Quotient (AQ) rendah. Berdasarkan pernyataan Adversity Reponse Profile (ARP) bahwa peserta didik tipe Campers kurang menggali banyak informasi ketika kurang memahama materi, kurang fokus dalam mendengarkan penjelasan guru, 
memiliki perjuangan yang kurang ketika belajar, kurang rajin dalam belajar untuk mengatasi kesulitan, dan ketika mengerjakan tugas tidak dikerjakan dengan serius yang penting selesai dan mengumpulkan. Sejalan dengan hasil penelitian Septianingtyas dan Jusra (2020) bahwa tipe Campers memiliki sedikit sifat mudah menyerah, dan kecemasan ketika terdapat soal baru yang sulit, dan kurang maksimal saat menyelesaikan masalah yang paling penting masalah cepat selesai. Permasalahan yang diselesaikan tidak dilakukan dengan sungguh-sungguh, mudah menyerah dan cepat puas. Sejalan dengan pendapat Sudarman (2012) peserta didik tipe Campers adalah peserta didik yang cepat puas dengan pencapaiannya, tidak ingin meneruskan usahanyan agar memperoleh hasil terbaik dari yang diperolehnya saat ini, dan takut untuk mengambil resiko yang besar. atas apa yang sudah diperolehnya.

Peserta didik tipe Quitters tidak muncul dalam penelitian ini. Quitters merupakan peserta didik dengan Adversity Quotient (AQ) rendah. Menurut Azaria \& Suprihatin (2017) tipe ini ialah seseorang yang melarikan diri dari segala permasalahan. Peserta didik akan lari menjauh dari masalah yang dihadapi, memilih mundur, dan tidak berani mengatasi permasalahan. Stoltz (2007) mngatakan bahwa quitters akan sulit mencapai kesuksesan, sehingga akan sulit mencapai hasil belajar yang maksimal.

Adversity Quotient (AQ) mempunyai 4 dimensi utama yaitu diemensi Control (kendali), Ownership and Origin (asal-usul dan pengakuan), Reach (jangkauan), dan Endurance (daya tahan). Dimensi tersebut yang selanjutnya memiliki peran penting dalam pembentukan Adversity Quotient (AQ) peserta didik. Nilai ketercapaian pada masing-masing dimensi Adversity
Quotient (AQ) peserta didik yang telah diperoleh dilihat pada gambar 2 .

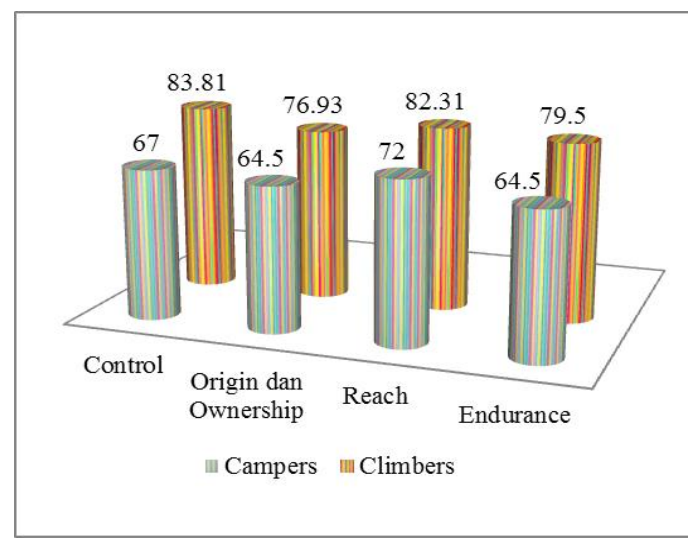

Gambar 2: Persentase Ketercapaian Dimensi Adversity Quotient (AQ) Tipe Climbers dan Campers

Peserta didik tipe climbers menunjukkan bahwa dimensi control memiliki persentase paling tinggi yaitu sebesar $83.81 \%$, dan peserta didik tipe campers memiliki persentase $67 \%$. Tipe climbers dan tipe campers memiliki nilai persentase yang baik pada dimensi control. Hal ini menunjukkan bahwa peserta didik mampu mengendalikan hal yang membuat kesulitan dalam belajar. Data tersebut didukung oleh pernyataan pada Adversity Reponse Profile (ARP) yang menjelaskan bahwa peserta didik mampu mengondisikan diri dari masalah, mampu mengendalikan masalah, mampu mengatasi kesulitan. Peserta didik tetap rajin belajar meskipun mendapatkan nilai di bawah KKM, peserta didik mampu mengendalikan diri untuk tidak marah ketika ada teman yang mengejek ketika memperoleh nilai ujian buruk, peserta didik mampu mengendalikan emosi ketika beradu pendapat dengan teman saat berdiskusi. Hal tersebut menunjukkan bahwa peserta didik mampu mengendalikan dirinya dengan baik terhadap kejadian yang menimbulkan kesulitan. Setiap peserta didik memiliki pengendalian diri berarti dapat mengendalikan respon terhadap kejadian yang terjadi di dalam 
hidupnya termasuk selama proses pembelajaran (Susanto, 2016).

Dimensi origin and ownership pada peserta didik tipe climbers dan campers memiliki persentase paling rendah dibanding dimensi lain. Peserta didik tipe climbers memiliki persentase $76.93 \%$, tipe campers memiliki persentase $64,5 \%$. Rendahnya dimensi origin and ownership menunjukkan bahwa peserta didik kurang memahami hal yang membuat kesulitan dalam belajar. Peserta didik kurang mencari penyebab kesulitan belajar yang menyebabkan rendahnya hasil belajar. Hal ini didukung dari Adversity Reponse Profile (ARP) pada dimensi origin and ownership yang menjelaskan bahwa peserta didik tidak mencari siapa penyebab kesulitan yang sedang dialami, tidak mencari apa penyebab kesulitan yang terjadi, tidak bertanggung jawab atas masalah, tidak mengakui akibat kesulitan. Peserta didik tidak mengetahui apa penyebab memperoleh hasil belajar yang rendah, dan beberapa peserta didik tidak mengumpulkan dan mengerjakan tugas karena tugas yang diberikan sulit. Dimensi origin memuat proses bagaimana peserta didik menganggap siapa atau apa yang menjadi penyebab asal usul kesulitan. Dimensi Ownership berhubungan dengan ranah tanggung jawab seseorang ketika mendapatkan kesulitan, dan sejauh mana seseorang mengakui akibat dari kesulitannya (Zuraida, 2018). Peserta didik yang memiliki Adversity Quotient yang rendah pada dimensi origin and ownership cenderung akan mempunyai perasaan bersalah yang tinggi terhadap kejadian buruk yang telah menimpah hidupnya (Susanto, 2016).

Dimensi reach pada peserta didik tipe campers memiliki persentase paling tinggi yaitu sebesar $72 \%$, sedangkan peserta didik tipe climbers memiliki nilai persentase sebesar $82.31 \%$. Hal ini menunjukkan bahawa peserta didik mampu mengetahui pengaruh masalah dengan baik, mangetahui sejauh mana kesulitan menjangkau ke segi lain, dan mampu membatasi kesulitan. Berdasarkan pernyataan pada Adversity Reponse Profile (ARP) yang diberikan pada peserta didik yang menjelaskan bahwa peserta didik belajar lebih giat untuk meningkatkan hasil belajar karena dapat mempengaruhi nilai raport, peserta didik teliti dalam mengerjakan soal ujian sehingga hasil yang dicapai sesuai harapan, ketika sedang belajar untuk ujian peserta didik tidak memikirkan hal lainnya karena hal tersebut dapat meningkatkan fokus belajar, peserta didik tetap pergi ke sekolah jika ada teman yang mengajak bolos, peserta didik tidak beralih ke tugas lain tetap fokus di satu tugas jika belum selesai dikerjakan, peserta didiki berani bertanya dan mengemukakan pendapat untuk menambah pengetahuan. Hal tersebut menunjukkan bahwa peserta didik mampu membatasi jangakaun permasalahan pada kejadian-kejadian yang dihadapi agar kesulitan tidak menjangkau ke segi lainnya. Peserta didik yang membatasi jangkauan ketika keadaan sulit akan memungkinkan untuk lebih berpikir jernih dalam mengambil suatu keputusan (Susanto, 2016).

Dimensi endurance pada peserta didik tipe climbers memiliki persentase sebesar $79.5 \%$ sedangkan pada tipe campers memiliki persentase rendah sebesar 64,5\%. Penyataan Adversity Reponse Profile (ARP) pada dimensi endurance berupa penguatan diri terhadap masalah, kemampuan bertahan terhadap masalah, dan mengetahui lamanya kesulitan yang dialami. Peserta didik tipe climbers cukup baik dalam mengetahui berapa lama kesulitan akan berlangsung dan berapa lama penyebabnya akan berlangsung, sedangkan tipe campers 
kurang dalam mengetahui berapa lama kesulitan akan berlangsung dan berapa lama penyebabnya akan berlangsung. Peserta didik tipe cilmbers berpikir bahwa kesulitan dalam belajar tidak akan mengganggu untuk waku yang cukup lama karena akan segera mengatasinya, sedanhgkan tipe campers kurang berusaha menguatkan diri ketika mendapatkan nilai yang rendah. Menurut Susanto (2016) dimensi endurance akan menganggap bahwa segala kesulitan tidak akan berlangsung lama, hanya besifat sementara dengan berusaha untuk memperbaiki dan mengatasinya.

Dimensi-dimensi pada Adversity Quotient (AQ) ini yang dapat mempengaruhi tinggi atau rendahnya Adversity Quotient (AQ) yang dimiliki peserta didik. Adversity Quotient (AQ) yang dimiliki pada setiap peserta didik akan berbeda. Perbedaan akan terlihat dari setiap dimensi Adversity Quotient (AQ). Contoh pada peserta didik tipe climbers memiliki persentase tertinggi pada dimensi control, sedangkan tipe campers memiliki persentase tertinggi pada dimensi reach. Setiap peserta didik memiliki nilai yang berbeda pada setiap dimensi. Menurut Azaria dan Suprihatin (2017) terdapat faktor yang mempengaruhi perbedaan Adversity Quotient (AQ) yang dimiliki oleh setiap peserta didik. Faktor yang mempengaruhi berkembangnya Adversity Quotient (AQ) yaitu daya saing, produktivitas, kreativitas, motivasi, mengambil resiko, perbaikan, ketekunan, dan belajar (Wulansari, 2017).

Adversity Quotient (AQ) yang dimiliki peserta didik dapat ditingkatkan dengan LEAD yaitu Listen, Explore, Analyze, dan Do. Listen (dengar) ialah peserta didik mendengarkan respon terhadap kesulitan. Explore mendorong peserta didik untuk menggali penyebab dari permasalahan, selanjutnya menggali berbagai pilihan langkah untuk mendapatkan penyelesaian yang tepat. Analyze ialah peserta didik dapat menganalisis sesuatu apa yang menjadi penyebab dirinya tidak bisa mengendalikan permasalahan. Do ialah peserta didik mampu mengambil langkah nyata untuk mengatasi kesulitan yang terjadi (Cerya, 2017).

\section{Hasil Belajar Biologi}

Hasil belajar biologi dapat diketahui dengan mengkategorikan nilai hasil belajar ketika Penilaian Akhir Tahun (PAT) mata pelajaran biologi pada semester genap 2021 yang diperoleh dari guru biologi. Kategorisasi rentang untuk hasil belajar dibagi menjadi 5 kategori menurut Purwanto (2013) yaitu sangat baik, baik, cukup, kurang, dan sangat kurang. Persentase nilai hasil belajar biologi yang telah diperoleh dapat dilihat pada gambar 3 .

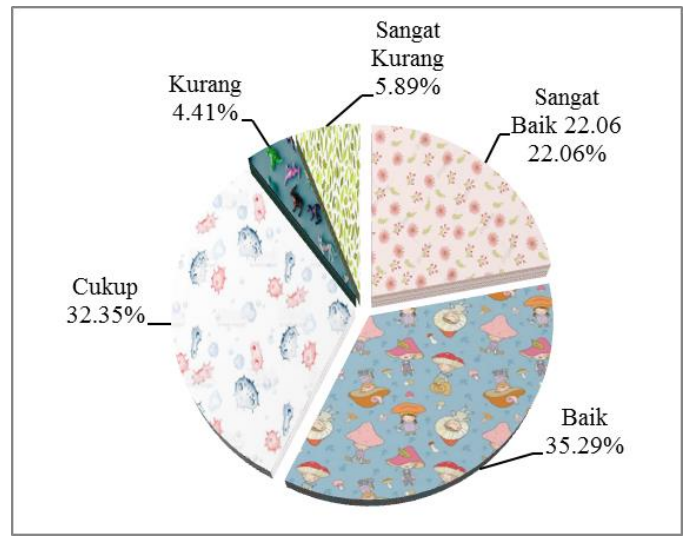

Gambar 3: Persentase Hasil Belajar Biologi

Persentase tertinggi hasil belajar biologi yang diperoleh peserta didik $35,29 \%$ termasuk ke dalam kategori baik. Hal ini didukung dari penyataan ARP bahwa peserta didik tetap rajin belajar meskipun mendapatkan nilai di bawah KKM, menggali banyak informasi jika ada materi yang kurang dipahami, berusaha membuat catatan pembelajaran di kelas, fokus mendengarkan penjelasan guru, berjuang sungguh-sungguh ketika belajar dan lebih giat untuk 
meningkatkan hasil belajar, dan tetap fokus ketika sedang belajar untuk ujian. Hal tersebut menunjukkan bahwa peserta didik memiliki perjuangan yang tinggi, memiliki kecerdasan dalam mengatasi kesulitan dan mampu mengubahnnya menjadi suatu keberhasilan, sehingga hasil belajar yang diperoleh dapat memuaskan. Keberhasilan peserta didik dalam pendidikan ditunjukkan dengan hasil belajar yang baik. Hasil belajar sebagai cerminan kemampuan penguasaaan seseorang atas mata pelajaran yang diajarkan oleh guru, peserta didik yang memiliki hasil belajar baik menunjukkan bahwa peserta didik tersebut memiliki tingkat kemampuan penguasaan yang tinggi terhadap mata pelajaran.

Peserta didik yang paling sedikit termasuk ke dalam kategori kurang sebesar 4,41\%. Meski hasil belajar peserta didik sudah baik namun masih ada $4,41 \%$ dari 68 siswa yang termasuk kategori kurang. Berdasarkan beberapa pernyataan pada ARP bahwa peserta kurang berjuang dengan sungguhsungguh ketika belajar, belajar yang kurang sehingga sehingga tidak dapat mengatasi kesulitan, kurang berani dalam bertanya untuk menambah pengetahuan, peserta didik kurang mengulang kembali materi yang telah di pelajari di sekolah untuk lebih memahami materi tersebut, kurang bertanya kepada guru jika ada materi yang sulit dan kurang dipahami, dan peserta didik kurang fokus belajar untuk ujian.

Hasil belajar biologi sebagai salah satu indikator dalam kesuksesan dan keberhasilan peserta didik pada proses pembelajaran harus didukung oleh banyak faktor, untuk memaksimalkan hasil yang diperolehnya. Tinggi rendahnya hasil belajar dipengaruhi oleh berbagai faktor. Faktor tersebut bisa berasal dari dalam diri maupun dari luar diri peserta didik. Faktor yang mempengaruhi hasil belajar terbagi menjadi dua yaitu faktor internal berupa psikologi, kecerdasan, perhatian, bakat, minat, motivasi, konsentrasi, kebiasaan belajar, kematangan, kelelahan, sikap terhadap belajar, dan kesehatan. Faktor eksternal berupa keluarga, sekolah, masyarakat, lingkungan sekitar, materi pelajaran, sarana prasarana, metode dan model guru mengajar, ruang belajar, teman bergaul dan dukungan sosial budaya. Faktor-faktor tersebut harus dimaksimalkan dengan baik karena dapat membantu peserta didik pada proses pembelajaran sehingga dapat memaksimalkan hasil belajar. Berdasarkan faktor tersebut Adversity Quotient (AQ) termasuk ke dalam salah satu kecerdasan seseorang dalam berjuang menghadapi permasalahan yang ditemui dalam proses belajar mengajar (Cerya, 2017).

3. Hubungan Antara Nilai Adversity Quotient (AQ) Terhadap Hasil Belajar Biologi

Hubungan antara nilai Adversity Quotient (AQ) dengan hasil belajar biologi menggunakan analisis korelasi Pearson Product Moment dengan syarat dilakukan uji prasyarat yaitu uji normalitas, uji homogenitas dan uji linearitas menggunakan SPSS versi 23. Hasil uji statistik berupa uji prasyarat ditampilakan pada tabel 1

Tabel 1. Hasil Uji Prasyarat

\begin{tabular}{|c|c|c|}
\hline Statistik & $\begin{array}{c}\text { Adversity } \\
\text { Quotient } \\
\text { (AQ) }\end{array}$ & $\begin{array}{c}\text { Hasil } \\
\text { Belajar } \\
\text { Biologi }\end{array}$ \\
\hline Uji Normalitas & 0,200 & 0,065 \\
\hline Uji Homogenitas & \multicolumn{2}{|c|}{0,325} \\
\hline Uji Linearitas & \multicolumn{2}{|c|}{0,728} \\
\hline
\end{tabular}

Hasil uji normalitas didapatkan nilai signifikansi untuk Adversity Quotient (AQ) sebesar 0,200 dan untuk hasil 
belajar biologi sebesar 0,065, menunjukan nilai signifikansi > 0,05 maka kedua data tersebut berdistribusi normal. Hasil uji homogenitas didapatkan nilai signifikasi sebesar $0,325>0,05$ artinya data tersebut dinyatakan homogen. Hasil pengujian linearitas didapatkan nilai sebesar $0,728>0,05$, maka terdapat hubungan yang linear secara signifikan antara kedua variabel. Hasil analisis statistik uji hipotesis dilihat pada tabel 2 .

Tabel 2. Hasil Uji Hipotesis

\begin{tabular}{|c|c|c|}
\hline Statistik & $\begin{array}{c}\text { Adversity } \\
\text { Quotient } \\
\text { (AQ) }\end{array}$ & $\begin{array}{c}\text { Hasil } \\
\text { Belajar } \\
\text { Biologi }\end{array}$ \\
\hline Uji Korelasi & \multicolumn{2}{|c|}{0,000} \\
\hline Pearson korelasi & 0,640 \\
\hline Uji Determinasi & 0,410 \\
\hline $\begin{array}{c}\text { Uji Regresi } \\
\text { Linear Sederhana }\end{array}$ & 0,000 \\
\hline
\end{tabular}

Hasil uji koefisien korelasi pada nilai Adversity Quotient (AQ) terhadap hasil belajar biologi ialah $0,000<0,05$, diputuskan bahwa kedua variabel memiliki hubungan. Nilai pearson korelasi yaitu 0,640 dan bernilai positif. Hubungan antara nilai Adversity Quotient (AQ) terhadap hasil belajar biologi termasuk ke dalam kriteria hubungan yang kuat didukung oleh Sugiyono (2014) kuat lemahnya hubungan dapat di interpretasi ke dalam beberapa kategori, hubungan yang kuat berada pada kategori 0,600,799 . Nilai positif menunjukkan bahwa semakin tinggi nilai Adversity Quotient (AQ) maka semakin tinggi pula nilai hasil belajar biologi peserta didik. Koefisien determinasi sebesar 0,410 yang artinya kontribusi Adversity Quotient (AQ) sebesar $41 \%$ terhadap hasil belajar biologi, sedangkan pengaruh faktor lain sebesar $59 \%$. Hasil uji regresi didapatkan nilai $0,000<0,05$ maka dikatakan terdapat pengaruh variabel $\mathrm{X}$ (Adversity Quotient (AQ)) terhadap variabel Y (hasil belajar biologi).

Hubungan antara nilai Adversity Quotient (AQ) terhadap hasil belajar biologi termasuk dalam hubungan yang kuat. Menurut Supardi (2015) Adversity Quotient (AQ) menjadi landasan untuk meningkatkan hasil belajar biologi peserta didik. Rata-rata Adversity Quotient (AQ) peserta didik berada pada kategori tinggi dengan persentase sebesar $94,11 \%$ dan hasil belajar biologi dengan kategori baik yaitu 35,29\%. Hal tersebut menunjukkan bahwa peserta didik memiliki perjuangan yang tinggi untuk memperoleh hasil belajar yang baik. Agustina dan Komalasri (2014) mengatakan Adversity Quotient (AQ) peserta didik mampu mendukung daya juang ketika menghadapi segala kesulitan yang muncul selama proses pembelajaran. Selama proses pembelajaran, peserta didik mempunyai kebutuhan untuk memperoleh hasil belajar yang baik yang harus terpenuhi. Usaha dalam meraih hasil belajar yang baik tidak mudah untuk di lalui, akan banyak kesulitan yang menimpahnya. Menurut Nurhayati dan Fajrianti (2015) Adversity Quotient (AQ) dipandang mampu mengatasi kesulitan dan sangat menunjang keberhasilan peserta didik untuk meningkatkan hasil belajar. Peserta didik dengan AQ tinggi akan lebih mampu menangani kesulitan yang dialami, akan tetapi bagi peserta didik dengan $\mathrm{AQ}$ rendah cenderung beranggapan bahwa kesulitan sebagai akhir dari segala perjuangan dan mengakibatkan hasil belajar menjadi rendah.

Hasil uji koefisien determinasi (r2) sebesar 0,410 artinya Adversity Quotient (AQ) memiliki kontribusi 
sebesar $41,0 \%$ terhadap hasil belajar biologi, sedangkan $59,0 \%$ dipengaruhi oleh faktor-faktor lain. Menurut Supardi (2015) Adversity Quotient (AQ) termasuk faktor yang sangat menentukan bagi kesuksesan rohani dan jasmani, karena pada dasarnya setiap peserta didik memiliki keinginan untuk meraih kesuksesan. Menurut Supardi faktor lain dalam ikhtiar untuk meningkatkan hasil belajar yaitu faktor dalam diri, faktor luar diri dan pendekatan belajar. Faktor tersebut jika dimaksimalkan akan sangat membantu peserta didik meningkatkan hasil belajar.

Hasi uji regresi didapatkan nilai signifikansi sebesar $0,000<0,05$ dikatakan bahwa terdapat pengaruh variabel X (Adversity Quotient (AQ)) terhadap variabel $\mathrm{Y}$ (hasil belajar biologi). Hasil hipotesis ini sejalan dengan penelitian Nurhayati dan Fajrianti (2015) menyimpulkan bahwa adversity quotient berpengaruh terhadap motivasi berprestasi. Seseorang yang memiliki Adversity Quotient (AQ) tinggi termasuk ke dalam orang orang yang memiliki motivasi yang baik. Peserta didik setelah mampu mengatasi segala kesulitan, maka selanjutnya Adversity Quotient (AQ) akan memicu munculnya motivasi belajar. Peserta didik dengan Adversity Quotient (AQ) tinggi cenderung dapat mengatasi segala kesulitan dan memiliki motivasi yang tinggi untuk mencapi hasil belajar yang baik. Hal tersebut harus menjadi acuan pada peserta didik untuk dapat meningkatkan kemampuan dalam mengatasi kesulitan sehingga mampu meningkatkan hasil belajar dan menjadi peserta didik yang berprestasi. Sejalan dengan pendapat Rukmana et al (2016) peserta didik yang memiliki Adversity Quotient (AQ) tinggi akan berusaha lebih dalam mengatasi permasalahan karena memiliki motivasi belajar yang tinggi. Hal tersebut akan mengantar peserta didik untuk mencapai hasil belajar biologi yang lebih baik.

Penelitian ini telah menemukan bahwa terdapat pengaruh Adversity Quotient (AQ) terhadap hasil belajar biologi. Adversity Quotient (AQ) peserta didik dalam belajar pastinya akan memberi pengaruh terhadap hasil belajar biologi, karena peserta diidik dituntut agar mampu menyelesaikan permasalahan-permasalahan dalam belajar. Menurut Utari dan Dewi (2020) kesadaran tentang pentingnya Adversity Quotient ( $A Q$ ) dalam proses pencapaian kesuksesan peserta didik membuat peserta didik terus berjuang dalam belajar, walaupun harus melalui banyak tantangan.

Hasil uji hipotesis menunjukkan bahwa hipotesis pada penelitian ini diterima. Andyani dan Indryawati (2018) menyatakan bahwa Adversity Quotient (AQ) yang baik membantu peserta didik dalam membangun semangat belajar dan membantu dalam melewati masa yang sulit karena berhasil memaksimalkan potensi sehingga dapat mempengaruhi hasil belajar secara positif. Sejalan dengan pendapat Williams dan Bryan (2013) Adversity Quotient (AQ) yang baik akan membantu peserta didik memperoleh kekuatan agar tetap fokus untuk teteap berprestasi di sekolah biarpun didera banyak permasalahan di sekolah dan di keluarga.

Hubungan antara Adversity Quotient (AQ) dengan hasil belajar biologi di dalam proses pembelajaran merupakan faktor yang sangat penting untuk mencapai keberhasilan dalam hasil belajar biologi peserta didik, karena kecerdasan akademik saja tidak cukup untuk memberikan kesiapan kepada peserta didik ketika menghadapi kegagalan secara akademis, sehingga peserta didik harus ditanamkan Adversity Quotient (AQ). 
Menurut Utami et al (2014) Adversity Quotient (AQ) menghasilkan banyak pengaruh yang positif bagi kehidupan dan mengakibatkan seseorang untuk selalu berpikir dan bertindak positif.

Peserta didik dengan nilai Adversity Quotient (AQ) tinggi memiliki hasil belajar biologi yang sangat baik. Hal tersebut ditunjukkan dengan nilai Adversity Quotient (AQ) yang diperolehnya tinggi pada msing-masing dimensi yang menujukkan bahwa dimensi Adversity Quotient (AQ) dalam peserta didik tersebut terpenuhi dengan baik. Menurut Rukaman et al (2016) dalam penelitiannya bahwa Adversity Quotient (AQ) dapat mempengaruhi peserta didik dalam menyelasikan permasalahan belajar seperti permasalahan memahami soal, permasalahan memahami materi yang sulit, dan segala permaslahan dalam pembelajaran biologi. Sejalan dengan pendapat Huda dan Mulyana (2017) bahwa peserta didik dengan Adversity Quotient tinggi lebih mampu menyelesaikan masalah dalam pembelajaran bioloig dan hal tersebut membantunya dalam mendapatkan hasil belajar yang baik pada pembelajaran biologi.

Setiap orang diyakini memiliki kecenderungan terhadap kecerdasan tertentu. Menurut Armstrong (2005) bahwa setiap peserta didik memiliki kapasitas dalam menampung kecerdasan yang berbeda-beda. Hal tersebut menunjukkan bahwa seseorang dengan hasil belajar rendah belum tentu hanya di pengaruhi dari faktor Adversity Quotient (AQ) saja. kecerdasan tersebut bergantung pada bagaimana peserta didik tersebut mengembangkan kecerdasan yang ada dalam dirinya secara optimal dengan proses pembelajaran yang telah dilakukan. Menurut Supardi (2015) dalam kehidupan merupakan hal yang lazim jika terdapat peserta didik yang mempunyai tingkat kecerdasan yang berbeda. Kecerdasan dianggap sebagai sesuatu yang tidak mutlak, karena kecerdasan tiap orang berbeda-beda. Sejalan dengan pendapat Nurhayati dan Fajrianti (2015) pada dasarnya kecerdasan setiap orang berbeda-beda, tingkat kemampuan inilah yang berdampak pada kemampuan seseorang dalam kesanggupannya menjalani kehidupan ini.

\section{KESIMPULAN}

Hasil penelitian didapatkan bahwa terdapat hubungan antara nilai Adversity Quotient (AQ) terhadap hasil belajar biologi kelas XI MIPA 1 dan XI MIPA 3 di SMAN 13 Kabupaten Tangerang. Hubungan antara nilai Adversity Quotient (AQ) terhadap hasil belajar biologi termasuk hubungan yang kuat dan bernilai positif dengan nilai person korelasi sebesar 0.640 . Semakin tinggi Adversity Quotient (AQ) maka semakin tinggi pula hasil belajar biologi peserta didik. Kontribusi Adversity Quotient (AQ) sebesar 41,0\% terhadap hasil belajar biologi. Rata-rata nilai Adversity Quotient (AQ) peserta didik berada pada kategori tinggi termasuk tipe climbers dengan persentase sebesar $94,11 \%$ dan hasil belajar biologi dengan kategori baik yaitu 35,29\%. Hal ini menunjukka bahwa peserta didik memiliki kecerdasan daya juang yang tinggi untuk memperoleh hasil belajar yang baik.

\section{DAFTAR PUSTAKA}

Agustina, T. S., \& Komalasai, P. T. (2014). Kecerdasan Adversiti (Adversity Quotient) Berdasarkan Jender Pada Mahasiswa Yang Mengikuti Executive Territory Program. Jurnal Ekonomi Dan Bisnis, 2(3), 206-215. 
Armstrong, T. (2005). Setiap Anak Cerdas! Panduan Membantu Anak Belajar dengan Memanfaatkan Multiple Intelligence. Jakarta: PT Gramedia Pustaka Utama.

Azaria, U. N \& T. Suprihatin. (2017). Adversity Quotient Pada Siswa Homeschooling. Jurnal Proyeksi, 12(2), 79-86.

Cerya, E. (2017). Peningkatan Adversity Quotient Dalam Pencapaian Prestasi Akademik Di Perguruan Tinggi. Jurnal Pakar Pendidikan, 15(2), 18-27.

Huda, N \& D. Damar. (2021). Asosiasi Adversity Quotient dengan Hasil Belajar Matematika Peserta Didik Jenjang SMP. Journal of Instructional Mathematics. 2(1), 10-20.

Kusnani, M. N. D., \& Rahayu, H. M. (2016). Analisis Butir Soal Ulangan Akhir Semester Ganjil Pada Mata Pelajaran Biologi Kelas X MIA SMA Negeri 1 Sungai Raya. Jurnal Biologi Education, 3(2), 53-62.

Nurhayati \& N.Fajrianti. (2015). Pengaaruh Adversity Quotient (AQ) Dan Motivasi Berprestasi Terhadap Prestasi Belajar Matematika. Jurnal Formatif. 3(1), 72-77.

Priyayi, D. F., Keliat, N. R., \& Hastuti, S. P. (2018). Masalah Dalam Pembelajaran Menurut Perspektif Guru Biologi Sekolah
Menengah Atas (SMA) Di Salatiga Dan Kabupaten Semarang. Jurnal Penelitian Pendidikan Biologi, 2(2), 85-92.

Purwanti, P \& D.R Munandar. (2019). Analisis Tingkat Adversity Quotient (AQ) Siswa SMA Pada Pembelajaran Matematika Melalui Problem Based Learning (PBL). Jurnal UNSIKA, 1(3), 3344.

Ronnie. M. D. (2006). The Power of Emotional \& Adversity Quotient (AQ) for Teachers: Menghadirkan Prinsip-Prinsip Kecerdasan Emosional dan Adversitas dalam Kegiatan Belajar Mengajar. Jakarta: Hikmah (PT Mizan Publika).

Rukmana, I., M. Hasbi., B. Paloloang. (2016). Hubungan Adversity Quotient Dengan Hasil Belajar Matematika Siswa Kelas XI SMA Negeri Model Terpadu Madani Palu. Jurnal Elektronik Pendidikan Matematik Tadulako, 03(03), 325-333.

Septianingtyas, N \& H. Jusra. Keampuan Pemecahan Masalah Matematis Peserta Didik Berdasarkan Adversity Quotient. Jurnal Pendidikan Matematika, 04(02), 657-672.

Stoltz, P. G. (2007). Adversity Quotient "Mengubah Hambatan Menjadi Peluang”. Jakarta: PT Grasindo.

Sudarman. (2012). Adversity Quotient: Kajian Kemungkinan 
Pengintegrasiannya

Pembelajaran

AKSIOMA, 1(1), 55-62.

Sugiyono. (2016). Metode Penelitian

Pendidikan Pendekatan

Kuantitatif, Kualitatif, dan $R \& D$.

Bandung: Alfabeta.

Suhartono. (2017). Adversity Quotient

Mahasiswa Pemograman Skripsi

(Adeversity Quotinet of Student

Programming Thesis).

Matematika Dan Pembelajaran, 5(2), 209-220.

Supardi, U. (2015). Pengaruh Adversity

Qoutient terhadap Prestasi

Belajar Matematika. Formatif: Jurnal Ilmiah Pendidikan MIPA, 3(1), 61-71.

Susanto, A. (2016). Daya Juang Dua Siswa Kelas $\mathrm{X}$ Bidang IPA Ditinjau Dari Pendekatan Eksistensial Di SMA Charitas Jakarta. Psiko Edukasi, 14(1), 18-27.

Utami, S., H.F. Nashori., M.A. Rachmawati. (2014). Pengaruh Pelatihan Adversity Quotient (AQ) Untuk Meningkatkan Motivasi Siswa Sekolah Menengah Pertama. Jurnal Intervensi Psikologi. 6(1), 131149.

Williams, J. M. \& Bryan, J. (2013). Overcoming adversity: Highachieving African American youth's perspectives on education resilience. Journal of Counseling \& Development, 9(1), 291-300.
Wulansari, Y. (2017). Gambaran Adversity Quotient Dan Faktor Yang Mmempengaruhi Pada Andikpas Di Lembaga Pembinaan Khusus Kelas II Bandung. Diakses dari: http://repository.unpad.ac.id./fro ntdoor/index/docl /35396

Zamzami, Sakdiah, \& Nurbaiza. (2020). Analisis Faktor Kesulitan Belajar Mata Pelajaran Biologi Siswa Kelas X SMA Negeri 1 Krueng Barona Jaya Kabupaten Aceh Besar. Jurnal Dedikasi Pendidikan, 4(1), 123-133.

Zuraida. (2018). Hubungan Adversity Quotient Dengan Prokrastinasi Akademik Dalam Penyelesaian Skripsi Pada Mahasiswa Yang Bekerja Di PTS Universitas Potensi Utama. Jurnal Kognisi, 2(2), 136-147. 